\title{
Correction To: Detection and diversity of maize yellow mosaic virus infecting maize in Nigeria
}

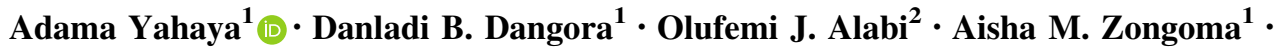 \\ P. Lava Kumar ${ }^{3}$
}

Published online: 5 April 2020

(C) Indian Virological Society 2020

Correction To: VirusDis. (October-December 2019) 30(4):538-544

https://doi.org/10.1007/s13337-019-00555-0

In the original publication of the article, Figures 1 and 2 were interchanged. The correct Figs. 1 and 2 are given below:

The original article can be found online at https://

doi.org/10.1007/s13337-019-00555-0.

Adama Yahaya

Yadamcy@yahoo.com; ayahaya@abu.edu.ng

1 Department of Botany, Faculty of Life Sciences, Ahmadu Bello University (ABU), Zaria, Kaduna State, Nigeria

2 Department of Plant Pathology and Microbiology, Texas A\&M AgriLife Research and Extension Center, Weslaco, TX, USA

3 International Institute of Tropical Agriculture (IITA), Oyo Road, Ibadan, Nigeria 

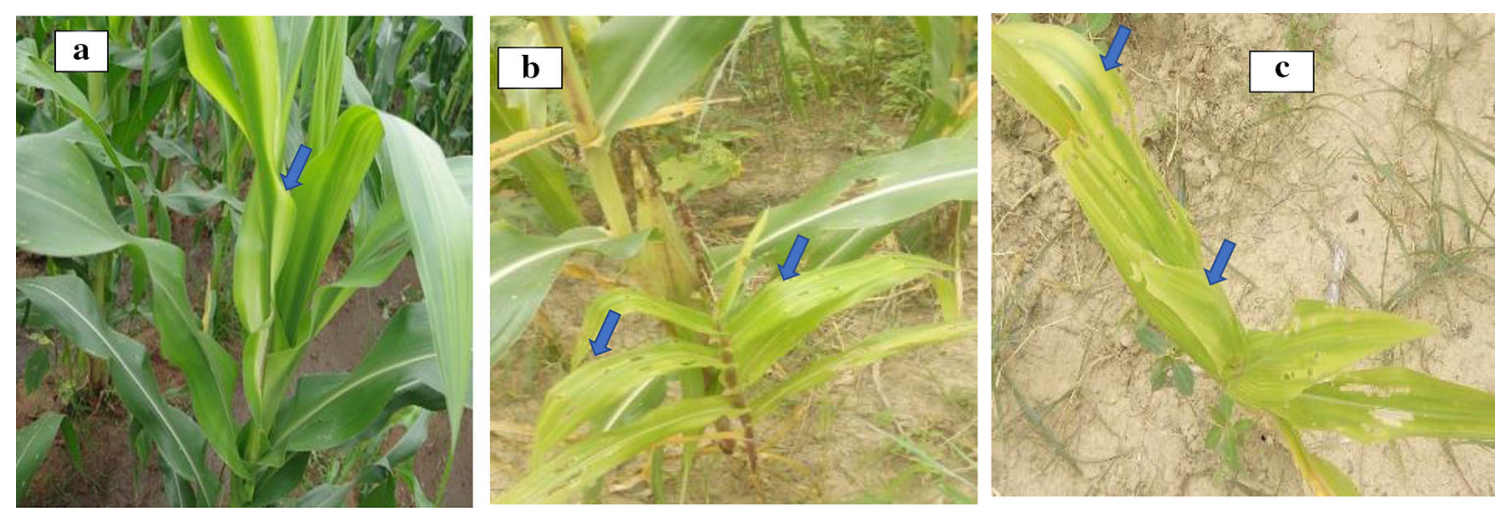

Fig. 1 Virus-like symptoms observed on maize plants in Kaduna and Katsina states, Nigeria. The observed symptoms included (a) wide yellow stripes that may sometimes be accompanied with $(\mathbf{b}, \mathbf{c})$ stunted growth. Symptomatic plants tested positive by RT-PCR for maize yellow mosaic virus (MaYMV)
Fig. 2 Unrooted minimum evolution phylogenetic tree $(\mathrm{K} 2+\mathrm{G}+1)$ depicting evolutionary relationships among global isolates of maize yellow mosaic virus (MaYMV) based on analysis of $\sim 1100 \mathrm{bp}$ nucleotide sequences encompassing the partial P1-P2 fusion protein and coat protein genes of MaYMV. The analysis was performed with the MEGA7 program [15] with 1000 bootstrap replications. $M Z$ maize, $S C$ sugarcane, IGRS itch grass, $S G$ Sorghum, $P N$ Panicum

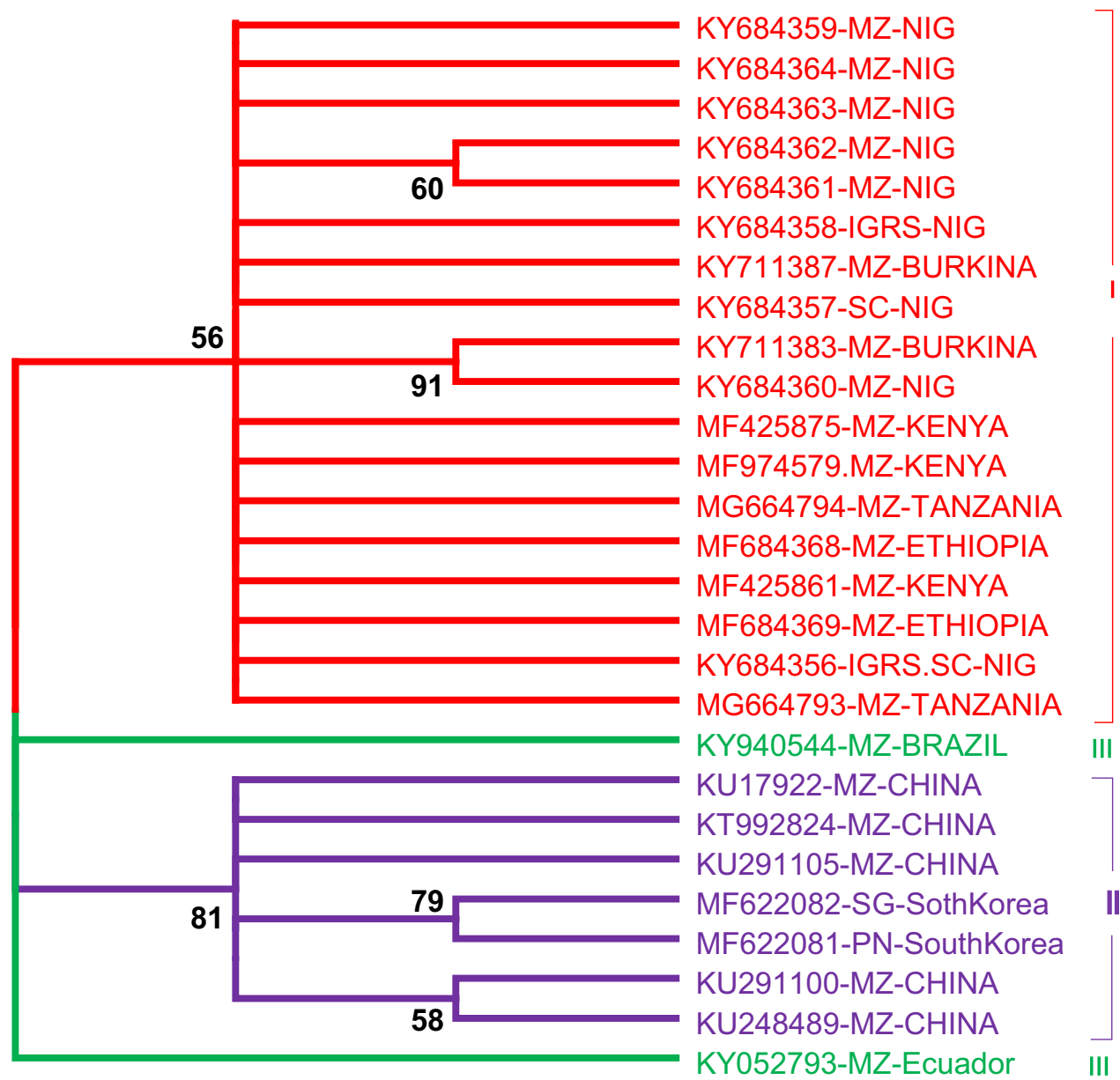

